\title{
Effect of Fe on Nitrogen Removal Rate and Microbes of Anammox
}

\author{
Bing Wang ${ }^{1}$; Bing Sun ${ }^{1 *}$; Yunlong Liu ${ }^{1}$; Lin Yang ${ }^{1}$ \\ ${ }^{1}$ School of Municipal and Environmental Engineering, Shenyang Jianzhu University, Shenyang Liaoning 110168, P.R.China;
}

\begin{abstract}
With the anammox sludge as the inoculation sludge, the effect of different concentrations of $\mathrm{Fe}^{2+}$ and $\mathrm{Fe}^{3+}$ on the denitrification performance of the anammox reaction was explored by setting a control experiment.The results showed that when the $\mathrm{Fe}^{2+}$ concentration was $0.08 \mathrm{mmol} / 1$, the reactor had the best removal efficiency, the removal rate of $\mathrm{NH}_{4}{ }^{+}-\mathrm{N}$ was $89.14 \%$ after $60 \mathrm{~h}$, and the removal rate of $\mathrm{NO}_{2}^{-}-\mathrm{N}$ was $85.9 \%$. The positive effect of $\mathrm{Fe}^{3+}$ on the anammox reaction was similar to that of $\mathrm{Fe}^{2+}$. From reading the literature, it can be known that $\mathrm{Fe}$ has a positive impact on anammox microorganisms in three aspects by promoting microbial enrichment, promoting the production of functional enzymes, and promoting microbial granulation.
\end{abstract}

\section{Introduction}

With the rapid development of science and technology, industry and agriculture are increasingly prosperous, and the excessive use of chemical fertilizers, pesticides, and industrial raw materials has severely damaged the environment on which we depend ${ }^{[1]}$. When people enjoy the convenience brought by advanced technology, they must also face the harm caused by environmental pollution to human beings. Among them, nitrogen is an environmental pollutant that cannot be ignored ${ }^{[2]}$. There are three common types of soluble inorganic nitrogen ions in aquatic ecosystems, such as ammonium $\left(\mathrm{NH}_{4}^{+}\right)$, nitrite $\left(\mathrm{NO}_{2}{ }^{-}\right)$, and nitrate $\left(\mathrm{NO}_{3}{ }^{-}\right)$, which can not only be degraded by the atmosphere, but also natural effects such as surface and groundwater runoff. Pollution generated by human activities such as industrial wastewater and domestic sewage discharge can enter the aquatic ecosystem ${ }^{[3]}$.

The Annamox reaction is a process in which $\mathrm{NH}_{4}{ }^{+}$ and $\mathrm{NO}_{2}{ }^{-}$are reactants to finally generate $\mathrm{N}_{2}$ and $\mathrm{NO}_{3}{ }^{-}$, and does not require aeration and additional carbon source ${ }^{[4]}$. Compared with traditional nitrification and denitrification, the operating cost is low, the sludge production is small, the nitrogen removal conversion rate is higher, and it is a more ideal biological nitrogen removal method [5]. However, the metabolism of anammox microorganisms is slow and the generation cycle is long, which severely restricts the efficiency of nitrogen removal ${ }^{[6]}$. Therefore, how to achieve stable operation of Annamox is a problem that scholars all over the world need to study in depth.

Some scholars have found that a proper concentration of iron can promote the growth of anammox microorganisms and combine with the $\mathrm{OH}^{-}$in the reaction, which can control the $\mathrm{pH}$ of the reactor within an appropriate range ${ }^{[7]}$. In this paper, anammox sludge is used as inoculation sludge, and the influence of different concentrations of $\mathrm{Fe}^{2+}$ and $\mathrm{Fe}^{3+}$ on the denitrification performance of anammox reaction is explored by setting up a control experiment.

\section{Experimental method}

\section{1 experimental method}

Take the anammox sludge cultured in the system, and study the short-term effect of $\mathrm{Fe}^{2+}$ on the activity of anammox bacteria through batch experiments. The specific test process was as follows:

(1) Take out the fresh sludge from the anammox reactor, and wash the residual matrix on the sludge with phosphate buffer. Weigh $5 \mathrm{~g}$ of cleaned wet sludge into a serum bottle of the same specification (100ML), and take some sludge to measure MLVSS;

(2) Add $50 \mathrm{ml}$ of test wastewater to the serum bottle (and keep the ammonia nitrogen concentration in the serum bottle at $50 \mathrm{mg} / \mathrm{L}$ and the nitrite concentration at $66 \mathrm{mg} / \mathrm{L})$. In the test group, $\mathrm{FeSO}_{4} \cdot 7 \mathrm{H}_{2} \mathrm{O}$ was added as needed, while in the control group, $\mathrm{Fe}^{2+}$ was not added. The rubber stopper was plugged and reinforced with an aluminum cap to keep the serum bottle airtight. According to Daverey et al., when the biomass concentration is low $(<2000 \mathrm{mg} / \mathrm{L})$, the impact of heavy metals is more significant. Therefore, the biomass concentration was kept below $2000 \mathrm{mg} / \mathrm{L}$ to detect the effect of $\mathrm{Fe}^{2+}$ on anammox activity. Short-term impact.

(3) Each serum bottle was blown off with $97 \%$ nitrogen for 10 minutes. After blowing off the air from

\footnotetext{
*Corresponding author mailbox：415494033@qq.com
} 
the upper part of the serum bottle, it was placed in a constant temperature water bath shaker at $35^{\circ} \mathrm{C}$ and 150 $\mathrm{rpm}$. When the temperature in the serum bottle rose to $35^{\circ} \mathrm{C}$, use a glass needle to release the gas in the upper part of the serum bottle to keep the pressure balanced. From then on, measure the volume of the gas in the upper part of the serum bottle every hour; the initial $\mathrm{pH}$ is fixed at 7.8, argon Purge to maintain anaerobic conditions. The generation of $\mathrm{N} 2 \mathrm{O}$ gas was tracked by measuring the overpressure in the headspace. The time-frequency depends on the biomass activity in each batch of experiments.

The effect of $\mathrm{Fe}^{2+}$ on the activity of anammox was studied by batch experiment. Five groups (three for each group) of different concentrations of $\mathrm{Fe}^{2+}$ batch experiments were carried out, respectively $0.02 \mathrm{mMol} / \mathrm{L}$, $0.04 \mathrm{mMol} / \mathrm{L}, 0.08 \mathrm{mMol} / \mathrm{L}, 0.16 \mathrm{mMol} / \mathrm{L}$, and a set of blank control group. (The $\mathrm{Fe}^{3+}$ group is the same as above).

\subsection{Analysis method}

$\mathrm{n}$ the process of reaction, $\mathrm{pH}$ value was determined by $\mathrm{pH}$ meter. $\mathrm{NH}_{4}^{+}-\mathrm{N}$ was determined by $\mathrm{NaCl}$ reagent spectrophotometry, $\mathrm{NO}_{2}^{-}-\mathrm{N}$ was determined by $\mathrm{N}^{-1}$-naphthalene - ethylenediamine spectrophotometry, $\mathrm{NO}_{3}^{-}$was determined by ultraviolet spectrophotometry [8].

\section{Results and analysis}

\subsection{Nitrogen changes}

The changes in the concentration of ammonia nitrogen and nitrite nitrogen in different control groups were shown in the figures. It can be seen from Figure 1 and Figure 2 that the addition of $\mathrm{Fe}^{2+}$ concentration had a positive effect on the ammonia nitrogen removal rate. At the 60th hour, the effluent concentration of ammonia nitrogen in the blank group was $9.8 \mathrm{mg} / \mathrm{L}$, the concentration of nitrite nitrogen was $15.9 \mathrm{mg} / \mathrm{L}$, and the removal rates of ammonia nitrogen and nitrite nitrogen were $80.4 \%$ and $75.9 \%$, respectively. When the $\mathrm{Fe}^{2+}$ concentration was $0.02 \mathrm{mM} / \mathrm{L}$ and $0.04 \mathrm{mM} / \mathrm{L}$, the removal rates of ammonia nitrogen and nitrite nitrogen were higher than those of the blank group. When the $\mathrm{Fe}^{2+}$ concentration was $0.08 \mathrm{mM} / \mathrm{L}$, the ammonia nitrogen removal effect was the best, and the removal rates of ammonia nitrogen and nitrite nitrogen were $89.14 \%$ and $85.9 \%$, respectively. When the $\mathrm{Fe}^{2+}$ concentration was $0.16 \mathrm{mM} / \mathrm{L}$, the effluent ammonia nitrogen and nitrite nitrogen concentrations were not much different from the $\mathrm{R}\left(\mathrm{Fe}^{2+}: 0.08 \mathrm{mM} / \mathrm{L}\right)$ group. As shown in Figure 3 and Figure 4, the effect of adding different concentrations of $\mathrm{Fe}^{3+}$ on the denitrification efficiency of the reactor was similar to that of $\mathrm{Fe}^{2+}$. Among them, the removal rates of ammonia nitrogen and nitrite nitrogen in the blank group after 60 hours were $78.5 \%$ and $73.1 \%$. When the $\mathrm{Fe}^{3+}$ concentration was $0.08 \mathrm{mM} / \mathrm{L}$, the nitrogen removal rate increased by up to about $7 \%$ compared with the blank group. It can be seen from the results that in the short term, different concentrations of $\mathrm{Fe}^{2+}$ and $\mathrm{Fe}^{3+}$ had similar effects on the reaction effect, and the difference in valence had no obvious effect. It is worth noting that when the $\mathrm{Fe}^{2+}$ concentration was $0.16 \mathrm{mM} / \mathrm{L}$, no obvious inhibition of the denitrification rate due to the high $\mathrm{Fe}$ concentration was observed. This is because anammox is a process of continuously producing $\mathrm{OH}^{-}$, and the $\mathrm{pH}$ in the reactor is constantly rising. When the $\mathrm{pH}$ in the reactor reaches a certain height, FE ions are very easy to generate $\mathrm{Fe}(\mathrm{OH})_{2}$ or $\mathrm{Fe}(\mathrm{OH})_{3}$ precipitation, thereby avoiding the excessively high $\mathrm{Fe}$ ion concentration that has a toxic inhibitory effect on anammox.

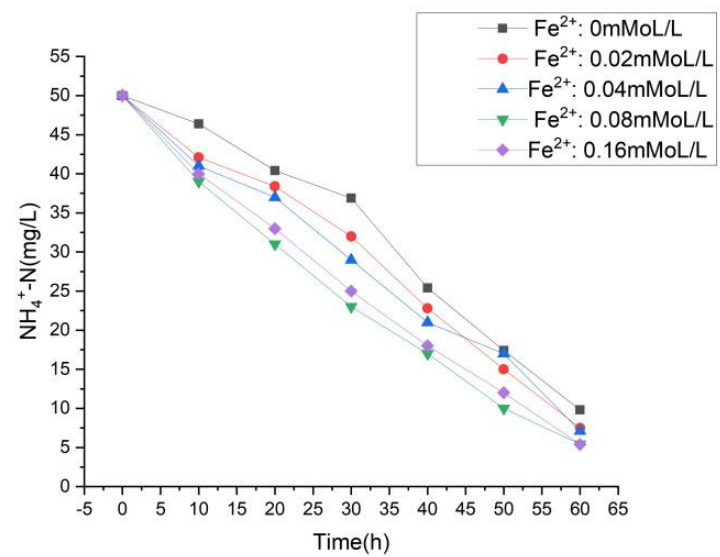

Figure.1 The concentration of $\mathrm{NH}_{4}{ }^{+}-\mathrm{N}$ under different concentrations of $\mathrm{Fe}^{2+}$

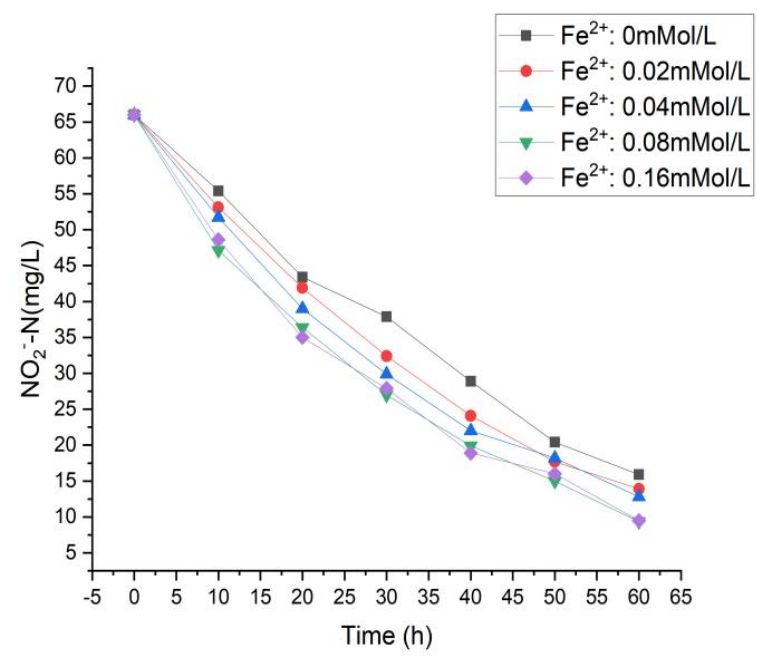

Figure.2 The concentration of $\mathrm{NO}_{2}^{-}-\mathrm{N}$ under different concentrations of $\mathrm{Fe}^{2+}$ 


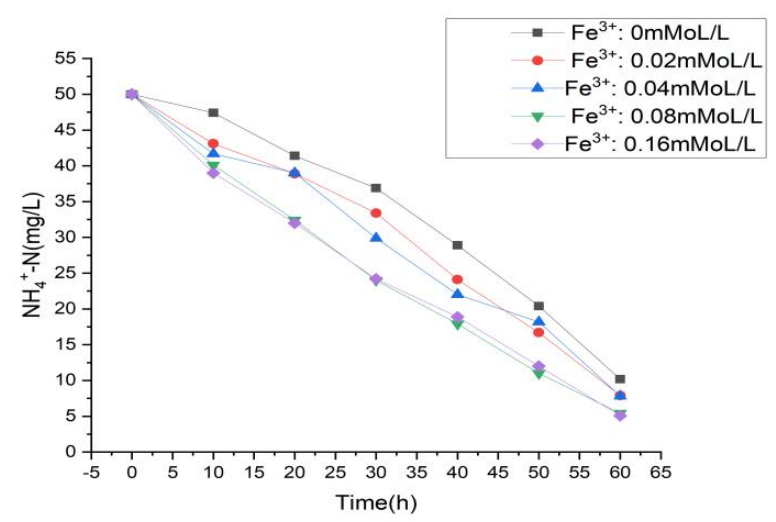

Figure. 3 The concentration of $\mathrm{NH}_{4}{ }^{+}-\mathrm{N}$ under different concentrations of $\mathrm{Fe}^{2+}$

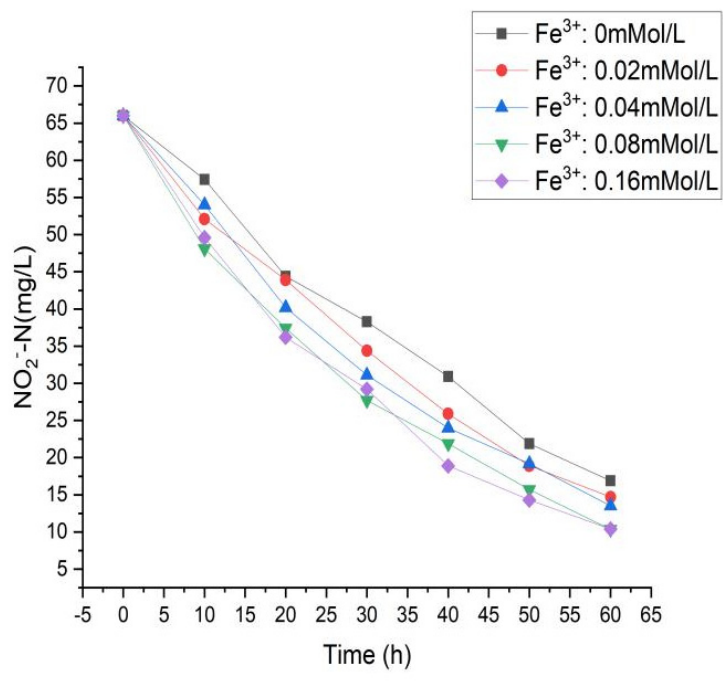

Figure.4 The concentration of $\mathrm{NH}_{4}{ }^{+}-\mathrm{N}$ under different concentrations of $\mathrm{Fe}^{2+}$

\subsection{The effect of iron on anammox sludge}

According to the literature, heme is the electron transfer center of cells, and the ferritin present in anammox bacteria can provide iron for heme, so iron plays an important role in the electron transfer process of anammox. In the anammox process, iron has three main influences on microorganisms: 1 Iron is an important element for the growth of anammox bacteria. A proper iron concentration can promote the enrichment of microbial communities and improve the denitrification capacity of microorganisms. 2 Iron is a component of heme, which is conducive to the production of functional continuous flow operation experiment enzymes in the reaction. 3 Iron has a positive effect on microbial granulation and accelerates the formation of granular sludge.

Some scholars have found that the $\mathrm{Fe}^{2+}$ and $\mathrm{Fe}^{3+}$ released after adding nano- $\mathrm{Fe}^{0}$ can reduce the dissolved oxygen in water and adjust the $\mathrm{pH}$, thereby reducing the activity of nitrite oxidizing bacteria (NOB) and benefiting the activity of anaerobic ammonia oxidizing bacteria (AOB). Studies have shown that an appropriate $\mathrm{Fe}^{2+} / \mathrm{Fe}^{3+}$ concentration can induce rapid transmission of the signal threshold in Anammox bacteria and improve bacterial activity. On the other hand, Liu et al. found through experiments that increasing the concentration of $\mathrm{Fe}^{2+}$ is beneficial to promote the growth rate of Anammox bacteria and the synthesis of heme c. When the concentration of $\mathrm{Fe}^{2+}$ increased from $0.03 \mathrm{mM} / \mathrm{L}$ to $0.09 \mathrm{mM} / \mathrm{L}$, the specific growth rate of anammox increased by $0.06 \mathrm{~d}$.

Anammox mostly uses granular sludge. Compared with flocculent sludge and biofilm, granular sludge has better settling performance and biochemical reaction capacity, so that the reaction denitrification efficiency is the highest ${ }^{[9]}$. The positive effect of iron on microbial granulation is mainly reflected in three aspects: 1 . Promote the secretion of extracellular polymer EPS; 2. Inhibit the growth of filamentous bacteria and improve the sedimentation performance of sludge ${ }^{[10]}$; 3 . Using salt bridge effect to adsorb Anammox bacteria to iron ions to promote sludge granulation4 The addition of iron promotes the production of microbial particles in the optimal particle size range. Studies have found that the activity of the granular sludge is highest when the particle size is in the range of $0.5-1 \mathrm{~mm}{ }^{[11]}$.

\section{Conclusion}

The experimental results showed that different concentrations of $\mathrm{Fe}^{2+}$ and $\mathrm{Fe}^{3+}$ have a positive effect on the anammox reaction, and there was no obvious difference due to the difference of valence. Among them, when the $\mathrm{Fe}$ ion concentration was $0.08 \mathrm{mM} / \mathrm{L}$, the denitrification effect was the best. Among them, the positive effects of $\mathrm{Fe}$ on a.nammox microorganisms are mainly divided into three aspects: promoting microbial enrichment, promoting the production of functional enzymes, and promoting microbial granulation.

\section{Acknowledgments}

1.Study on three-phase synergistic phosphorus recovery mechanism in anaerobic treatment of phosphorus rich wastewater (2019-ZD-0298), Project of Science and Technology Department of Liaoning Province, 2019,

2.Food waste induces surplus sludge to enhance the fermentation performance of L-lactic acid bacteria (1nqn202011), Project of Education Department of Liaoning Province, 2020.

\section{References}

1. Fan, X.; Guan, X.; Ma, J., et al., Kinetics and corrosion products of aqueous nitrate reduction by iron powder without reaction conditions control.[J] Journal of Environmental Sciences 2009, 21, (8), 1028-1035.

2. Li, X.; Li, J.; Xi, B., et al., Effects of groundwater level variations on the nitrate content of groundwater: a case study in Luoyang area, China.[J] Environmental Earth Sciences 2015, 74, (5), 
3969-3983.

3. Zawaideh, L. L.; Zhang, T. C., The effects of $\mathrm{pH}$ and addition of an organic buffer (HEPES) on nitrate transformation in $\mathrm{Fe} 0$-water systems.[J] Water Science and Technology 1998, 38, (7), 107-115.

4. Fan Xiaomeng,Guan Xiaohong,Ma Jun.The mechanism and influencing factors of reducing nitrate in water by zero-valent iron[J].China Water \& Wastewater,2008(14):5-9. (in chinese)

5. Vasudevan, S.; Epron, F.; Lakshmi, J., et al., Removal of NO3- from Drinking Water by Electrocoagulation - An Alternate Approach.[J] CLEAN - Soil, Air, Water 2010, 38, (3), 225-229.

6. Kiskira, K.; Papirio, S.; van Hullebusch, E. D., et al., Influence of $\mathrm{pH}, \mathrm{EDTA} / \mathrm{Fe}(\mathrm{II})$ ratio, and microbial culture on $\mathrm{Fe}(\mathrm{II})$-mediated autotrophic denitrification.[J] Environ Sci Pollut Res Int 2017, 24, (26), 21323-21333.

7. Oshiki, M.; Ishii, S.; Yoshida, K., et al., Nitrate-dependent ferrous iron oxidation by anaerobic ammonium oxidation (anammox) bacteria.[J] Appl Environ Microbiol 2013, 79, (13), 4087-93.

8. Xing, W.; Li, D.; Li, J., et al., Nitrate removal and microbial analysis by combined micro-electrolysis and autotrophic denitrification.[J] Bioresour Technol 2016, 211, 240-7.

9. Hao Zhiwei, Li Liang, Ma Luming. Research on the removal of nitrate in the pipeline by zero-valent iron reduction[J]. China Water \& Wastewater, 2008, 24 (17): 36-39. (in chinese)

10. Huang Xiaoming, Lan Yaling, Gao Dongsheng, et al. Research on the Kinetics of Groundwater Nitrate Reduction byZero-valent Iron[J].Environmental Science and Technology,2018,41(12):67-72. (in chinese)

11. Zhang Shude, Li Jie, Yang Hong, et al.. Study on the effect of nitrite on anammox[J].Environmental Pollution \& Control,2005(05):324-326+315. (in chinese) 